\title{
KOMUNIKASI ANTARBUDAYA DALAM MASYARAKAT MULTIKULTUR (Studi Kasus pada Karyawan Warga Negara Jepang dan Indonesia di PT. Tokyu Land Indonesia)
}

\author{
${ }^{1}$ Anita Febiyana, ${ }^{2}$ Ade Tuti Turistiati \\ Institut Ilmu Sosial dan Manajemen STIAMI \\ Email: ${ }^{1}$ mikafebi@gmail.com, ${ }^{2}$ ade.tuti.turistiati@gmail.com
}

\begin{tabular}{ll} 
ARTICLE INFO & ABSTRACT \\
\hline Keywords: & The purpose of this study was to analyze intercultural communication between \\
Intercultural & Japanese and Indonesian employees at PT. Tokyu Land Indonesia. This research \\
communication, & was also to analyze barriers which occurred in intercultural communication \\
Japanese and & between them, and how to overcome these barriers. The method used in this study \\
Indonesian, & was a qualitative research method with a case study approach. Data collection was \\
qualitative research & carried out by using an in-depth interview with 3 Japanese and 3 Indonesian \\
& employees, observation, and relevant previous research articles, and research- \\
& related documents. This research used the intercultural communication model of \\
& William B. Gudykunst and Young Yun Kim, intercultural communication concepts \\
& from Edward T. Hall, such as proxemics (the concept of distance), chronemics (the \\
& concept of time), high context and low context communication, individualism and \\
& collectivism, stereotypes. The results of the study showed that intercultural \\
& communication between Japanese and Indonesian employees at PT. Tokyu Land \\
& Indonesia is relatively good. Obstacles that occurred in intercultural \\
& communication are due to problems of differences and understanding of language, \\
& habits, respect for time (Japanese monochronic while Indonesia is polychronic), \\
and the existence of stereotypes from each nation. To overcome these obstacles, & they have to learn more about Japanese culture for Indonesian employees, and \\
Indonesian culture for Japanese employees, openness to confirm understanding of & the message delivered, mutual respect, and forgiveness each other if a \\
& misunderstanding occurs.
\end{tabular}

\section{PENDAHULUAN}

Interaksi manusia dari berbagai belahan dunia saat ini lebih mudah dengan adanya kemajuan teknologi informasi yang sangat pesat termasuk kemajuan dan meningkatnya transportasi. Setiap hari manusia dapat berkomunikasi dan berinteraksi dengan manusia lain dari berbagai belahan dengan adanya pertemuan langsung (face to face) atau melalui media, terutama media sosial. Pertemuan antarbudaya pun semakin mudah dan semakin banyak orang yang bepergian ke daerah atau negara lain untuk berbagai tujuan dan kepentingan, seperti liburan, belajar, bekerja, atau melakukan transaksi bisnis.

Perusahaan multinasional di berbagai negara dan perusahaan-perusahaan lokal yang mengembangkan bisnis ke negara-negara lain jumlahnya pun cenderung meningkat. Konsekuensinya keberadaan pekerja dan profesional asing di suatu negara atau orang bekerja di negara lain semakin banyak.

Direktur Jenderal Pembinaan Penempatan Tenaga Kerja dan Perluasan Kesempatan Kerja Kementerian Ketenagakerjaan (Kemnaker) Maruli Apul Hasoloan menjelaskan, jumlah TKA sampai akhir 2018 lalu mencapai 95.335 orang. Ini berarti terjadi peningkatan sekitar 10,88\% dibanding sepanjang tahun 2017 lalu yang mencapai 85.974 orang. Jika dirinci, dari TKA berjumlah 95.335 orang tersebut terdapat tenaga asing profesional sebanyak 30.626 orang, manajer berjumlah 21.237 orang dan adviser/konsultan/direksi 30.708 orang. Berdasarkan asal negaranya sampai tahun 2018 TKA yang bekerja di Indonesia masih didominasi China sebanyak 32.000 orang dan Jepang di urutan kedua sebanyak 13.897 orang, disusul Korea 9.686 orang, India 6.895 orang dan Malaysia sebanyak 4.667 orang.(Arifin, 2019) 
Orang-orang Jepang yang berada di Indonesia di antaranya bekerja di PT. Tokyu Land Indonesia. PT.Tokyu Land Indonesia merupakan salah satu dari Perusahaan Modal Asing (PMA) Jepang yang beroperasi di Indonesia. Perusahaan tersebut memiliki karyawan berkewarganegaraan Jepang dan Indonesia sehingga komunikasi antarbudaya pun tidak terhindarkan. Orang Indonesia yang bekerja di PT. Tokyu Land berasal dari etnik yang berbeda-beda pula, di antaranya etnik Sunda, Jawa, Batak, dan Minangkabau. Dengan kata lain, para karyawan di perusahaan tersebut adalah multikultur.

Setiap budaya yang berbeda memiliki sistem yang berbeda, oleh karena itu memahami cara berkomunikasi yang baik sangat penting. Cara berkomunikasi tidak terlepas dari bahasa, aturan dan norma yang dimiliki masing-masing individu.

PT.Tokyu Land memiliki karyawan warga negara Jepang 20 orang dan 133 orang Indonesia. Komunikasi yang terjadi antara karyawan warganegara Jepang dan Indonesia menggunakan 3 bahasa, yaitu bahasa Inggris, bahasa Indonesia, dan bahasa Jepang. Pada saat-saat tertentu dan suasana informal, orang-orang Indonesia dengan etnik yang sama menggunakan bahasa daerah yang mereka pahami bersama. Misalnya, sesama orang Sunda kadang-kadang berbicara dalam bahasa Sunda, sesama orang Jawa berbicara bahasa Jawa, dan sebagainya.

Para karyawan yang bekerja di PT. Tokyu Land Indonesia mempunyai masa kerja yang berbeda-beda. Bagi karyawan warga negara Indonesia maupun Jepang terutama yang relatif baru, perlu memahami budaya masing-masing dan perlu penyesuaian.

Perbedaan latar belakang budaya termasuk di dalamnya perbedaan norma yang dianut, bahasa, gaya bicara, adat istiadat, dan kebiasaan berpotensi menimbulkan masalah atau kesalahpahaman. Penelitian-penelitian terdahulu yang dipublikasikan dalam jurnal banyak membahas temuan bahwa perbedaan latar belakang budaya merupakan faktor yang dapat menimbulkan kesalahpahaman. (Arifin, 2019) dalam penelitiannya tentang komunikasi antarbudaya antara mahasiswa Indonesia dengan mahasiswa Vietnam, mengungkapkan bahwa perbedaan bahasa dan kesalahpahaman non-verbal, menimbulkan konflik. Selain itu hambatan karena prasangka dan stereotip pun cenderung menimbulkan konflik antarbudaya. Pelabelan terhadap suatu budaya, sementara mengenai kegelisahan yang tinggi karena kurangnya rasa percaya diri dan adanya kekhawatiran untuk tidak diterima oleh budaya lain menyebabkan rasa gelisah bagi para pelaku komunikasi untuk berinteraksi. (Turistiati, 2019b) dalam jurnal kajian antarbudaya mengenai komunikasi antarbudaya antara mahasiswa Indonesia dan mahasiswa Jepang, berpendapat bahwa tantangan yang dihadapi mahasiswa Indonesia menempuh pendidikan di Nara Jepang adalah karena faktor dari dalam (internal) dan dari luar (eksternal) individu. Proses adaptasi dilakukan untuk mengatasi hambatan yang dialami yaitu terutama karena faktor bahasa. Adaptasi dilakukan sebelum dan ketika mahasiswa tiba di negara Jepang. Faktor kesamaan agama, etnik, dan penguasaan bahasa yang sama merupakan 3 faktor utama yang mempermudah terjadinya proses adaptasi.

Setiap orang berpikir dan berperilaku berdasarkan pengalaman budayanya. Perubahan nilai budaya seiring dengan perkembangan zaman dan wawasan yang makin berkembang ini biasanya terjadi pada orang-orang yang secara tiba-tiba berpindah atau dipindahkan ke daerah yang baru. Hal tersebut dapat menimbulkan gegar budaya. Gagar budaya atau culture shock biasanya terjadi pada seseorang yang membandingkan kebiasaan setempat dengan lingkungan rumah, mulai dari kebersihan warganya, perlakukan terhadap waktu, tata cara, kesopanan, dan lain lain.

Berdasarkan uraian di atas peneliti menganalisis tentang komunikasi antarbudaya dalam Masyarakat Multikultur pada Karyawan Warga Negara Jepang dan Indonesia di PT. Tokyu Land Indonesia. Ruang lingkup penelitian ini berfokus pada komunikasi antarbudaya dalam masyarakat multikultural, yaitu komunikasi antara karyawan warga negara Jepang dan Indonesia di PT.Tokyu Land Indonesia, Jakarta. Dalam penelitian ini penulis mengacu pada model komunikasi antarbudaya dari William B. Gudykunst dan Young Yun Kim. Selain itu penulis menggunakan konsep-konsep dalam komunikasi antarbudaya dari Edward T. Hall seperti proksemik (konsep jarak), kronemik (konsep waktu), high context and low context communication, individualisme dan kolektivisme, stereotip. 


\section{TINJAUAN PUSTAKA}

Penelitian-penelitian terdahulu berkaitan dengan komunikasi telah banyak dilakukan. Subjek penelitian tersebut beraneka ragam misalnya antar etnik yang berbeda di Indonesia, antar orang Indonesia dengan bangsa lain, ataupun antar etnik di luar Indonesia, misalnya antara bangsa Amerika dan Jepang. Metode penelitian yang dipergunakan dalam penelitian itu pun berbeda, kuantitatif atau kualitatif dengan pendekatan yang berbeda pula, misalnya fenomenologi, studi kasus, dan sebagainya.

Hasil penelitian tentang komunikasi lintas budaya dalam Masyarakat Ekonomi Asean (MEA) menunjukkan bahwa hambatan bahasa merupakan faktor utama dalam melakukan komunikasi lintas budaya.(Rahayuningsih, 2014). Sementara itu, penelitian pola komunikasi antarbudaya pada Komunitas Warga Korea Hansamo di Bandung menunjukkan perlunya mengelola kecemasan dan ketidakpastian pada saat berinteraksi antara warganegara Korea dengan masyarakat Bandung. Hambatan yang ditemui ada pada adat budaya yang berbeda antara masyarakat Bandung dengan masyarakat Korea. (Aryandani, 2016). Sejalan dengan hasil penelitian Rahayuningsih, Aryandani pun menemukan bahwa faktor bahasa merupakan kendala utama dalam interaksi anatarbudaya.

Penelitian tentang komunikasi antarbudaya antara mahasiswa Malaysia dengan Mahasiswa Indonesia menunjukkan bahwa walaupun keduanya mempunyai banyak persamaan dan konten, namun logat dan gaya bahasa kadang-kadang menjadi kendala dan menimbulkan kesalahpahaman. (Siregar, 2017).

Ketika komunikasi dikaitkan dengan kebudayaan, beberapa pakar mendefinisikan komunikasi antarbudaya dalam berbagai sudut pandang. Komunikasi antarbudaya meliputi komunikasi yang melibatkan peserta komunikasi yang mewakili pribadi, antarpribadi, dan kelompok, dengan tekanan pada perbedaan latar belakang kebudayaan yang memengaruhi perilaku komunikasi para peserta. Dalam proses komunikasi antarbudaya, kebudayaan tidak boleh dilihat hanya sekedar adat istiadat. Kebudayaan meliputi pertukaran persepsi tentang diri sendiri dan orang lain, persepsi dan sikap terhadapsuatu objek seperti ruang, waktu, lingkungan, orang atau relasi dengan orang lain.(Liliweri, 2013)

Tubbs \& Moss (2008) dalam (Turistiati, 2019a) mendefinisikan:

"Intercultural communication as communication between members of different cultures (whether defined in terms of racial, ethnic, or socioeconomics differences)" (Komunikasi antarbudaya sebagaikomunikasi antara anggota-anggota dari budaya yang berbeda baikberbeda dalam ras, etnik maupun sosioekonomik)."

Setiap budaya yang berbeda memiliki sistem sistem yang berbeda pula, oleh karena itu memahami cara berkomunikasi yang baik sangat penting. Berbicara tentang cara berkomunikasi tidak lepas dari bahasa, aturan dan norma masing masing. Pertukaran komunikasi antarbudaya didefinisikan sebagai proses pertukaran simbolik dimana adanya individu individu dari setidaknya dua budaya yang berbeda.

Komunikasi antarbudaya penggunaannya sering dipertukarkan dengan komunikasi lintas budaya.(Griffin, 2006) berpendapat:

"The term cross-cultural communication is usually reserved fortheory and research that compare specific interpersonal variables such as convertional distance, selfdisclosure, and styles of conflictresolution across two or more different cultures." ("Istilah komunikasilintas-budaya biasanya disediakan untuk teori dan penelitian yangmembandingkan variabel interpersonal seperti jarak percakapan, keterbukaan diri, dan gaya penyelesaian konflik di dua atau lebihkebudayaan yang berbeda")

Dari beberapa definisi di atas dapat disimpulkan bahwa komunikasi antarbudaya adalah proses pertukaran pesan yang dilakukan seseorang melalui saluran tertentu kepada orang lain yang berasal dari latar belakang budaya yang berbeda dan menghasilkan efek tertentu.

Perkembangan kebudayaan dan kehidupan manusia serta hubungan kelompok manusia (masyarakat) terjadi dengan kelompok manusia lain. Hubungan tersebut masing-masing membawa kebudayaannya sendiri dan menimbulkan sebuah interaksi baru di antara keduanya, yaitu 
komunikasi antarbudaya. Komunikasi antarbudaya merupakan suatu peristiwa komunikasi di mana mereka yang terlibat di dalamnya berasal dari latar belakang yang berbeda.

Model William B. Gudykunst dan Young Yun Kim dalam (Mulyana, 2014) berpendapat sebenarnya merupakan model komunikasi antarbudaya, yakni komunikasi antara orang-orang yang berasal dari budaya yang berlainan, atau komunikasi dengan orang orang asing (stranger). Model komunikasi ini pada dasarnya sesuai dengan komunikasi tatap muka, khususnya antara dua orang. Meskipun disebut model komunikasi antarbudaya atau model komunikasi dengan orang asing, model komuniasi tersebut mempresentasikan komunikasi antara siapa saja, karena pada dasarnya tidak ada dua orang yang mempunyai budaya, sosiobudaya, dan psikobudaya yang persis sama.

Model Komunikasi antarbudaya dari Gudykunst dan Kim sebagai berikut:

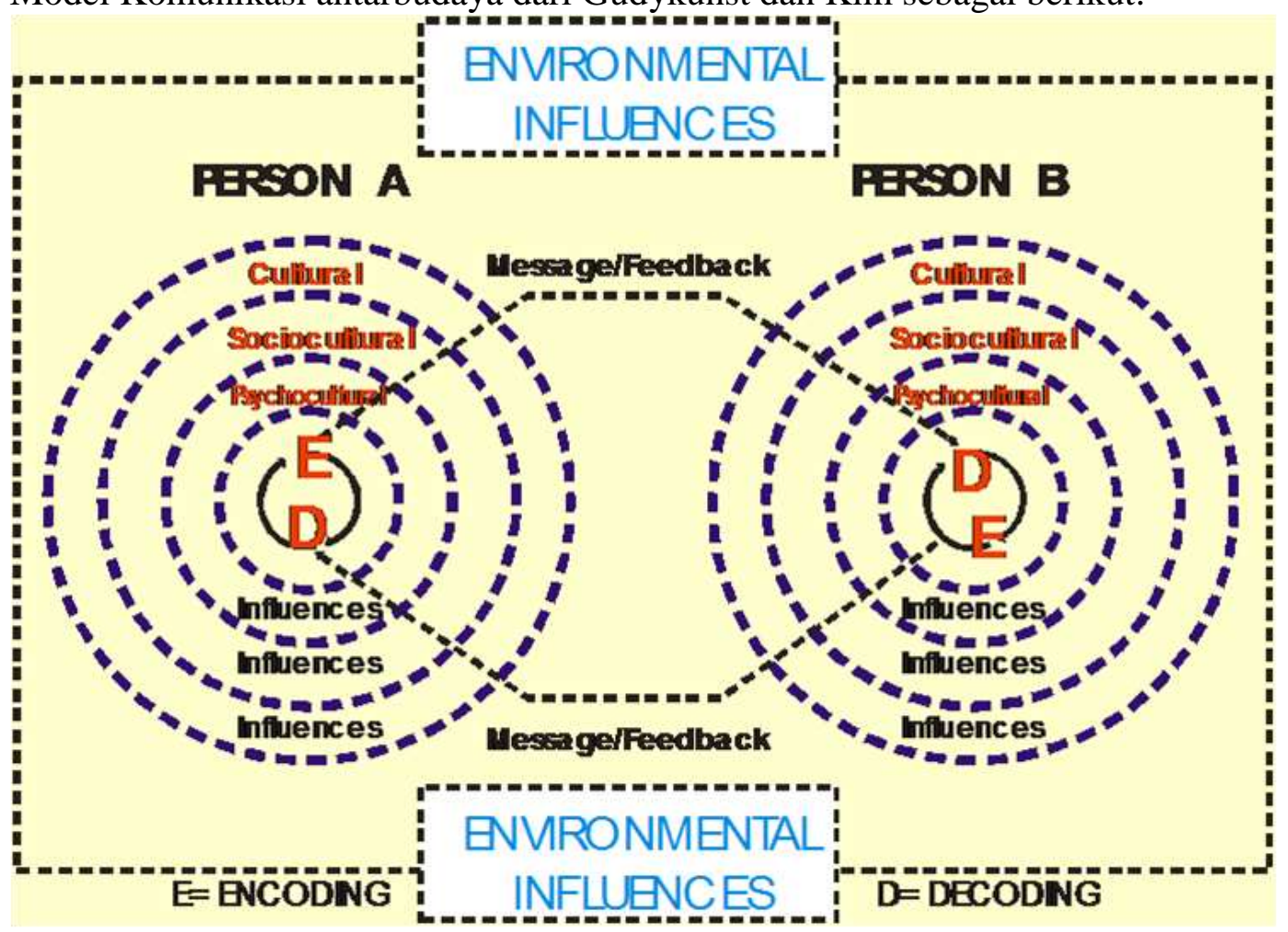

\section{Gambar 2.1 Model Komunikasi Antarbudaya Gudykunst \& Kim}

Sumber:http://commscience166a.blogspot.com/2012/10/model-komunikasi-gudykunst-danyoung.html, diakses tanggal 1 Mei 2019

Gudykunst dan Young Yun Kim mengasumsikan dua orang yang setara dalam berkomunikasi, masing-masing sebagai pengirim dan sekaligus sebagai penerima atau keduanya sekaligus melakukan penyandian atau (encoding) dan penyandian-balik (decoding). Karena itu tampak pula bahwa pesan suatu pihak sekaligus juga adalah umpan balik bagi pihak lainya. Pesan/umpan balik antara kedua peserta komunikasi direpresentasikan oleh garis dari penyandian seseorang ke penyendian-balik orang lain dan dari penyandian orang kedua ke penyendian orang balik orang pertama.

Kedua garis pesan/umpan balik menunjukkan bahwa setiap kita berkomunikasi secara serentak kita menyandi dan menyandi balik pesan. Dengan kata lain komunikasi tidak statis, kita tidak menyandi pesan dan tidak melakukan apa apa hingga kita menerima umpan balik. Alih alih kita memproses rangsangan yang datang (menyandi-balik) pada saat kita juga menjadi pesan.

Menurut Gudykunst dan Kim, penyandian pesan dan penyandian-balik pesan merupakan proses interaktif yang dipengaruhi oleh filter filter konseptual yang dikategorikan menjadi faktor faktor budaya, sosiobudaya, psikobudaya dan faktor lingkungan. Lingkaran paling dalam, yang mengandung interaksi antara penyandian pesan dan penyandian balik pesan, dikelilingi tiga 
lingkaran lainya yang mempresentasikan pengaruh budaya, sosiobudaya dan psikobudaya, berupa lingkaran lingkaran dengan garis terputus putus.

Garis terputus putus itu menunjukan bahwa budaya, sosiobudaya dan psikobudaya itu saling berhubungan atau saling memengaruhi kedua orang yang memwakili model juga berada dalam kontak dengan terputus putus yang mewakili pengaruh lingkungan. Garis terputus-putus yang membentuk kontak tersebut menunjukan bahwa lingkungan tersebut bukanlah suatu sistem tertutup atau terisolasi. Kebanyakan komunikasi antara orang orang berlangsung dalam lingkungan sosial yang mencangkup orang-orang lain yang juga terlibat dalam komunikasi.

Seperti ditujukan di atas bahwa pengaruh-pengaruh budaya sosiobudaya dan psikobudaya itu berfungsi sebagai filter konseptual untuk menyandi dan menyandi balik pesan. Filter tersebut adalah mekanisme yang membatasi jumlah alternatife yang memungkinkan kita memilih kita menyandi balik dan menyandi balik pesan. Lebih khusus lagi pesan filter tersebut membatasi prediksi yang kita buat mempengaruhi cara kita menyandi pesan. Lebih jauh lagi filter itu membatasi rangsangan apa yang kita perhatikan dan bangaimana kita menafsirkan rangsangan tersebut ketika kita menyandi balik pesan yang datang.

Gudykunst dan Kim berpendapat, pengaruh budaya dalam model itu meliputi faktor faktor yang menjelaskan kemiripan dan perbedaan budaya misalnya pandangan dunia (agama), bahasa juga sikap kita terhadap manusia, misalnya kita harus perduli terhadap individu (individualism) atau kelompok (kolektivisme). Faktor faktor tersebut memengaruhi nilai norma dan aturan yang mempengaruhi perilaku komunikasi kita.

Pengaruh sosiobudaya adalah pengaruh yang menyangkut proses penataan sosial (social ordering process). Penataan sosial berkembang berdasarkan interaksi dengan orang lain ketika pola pola perilaku menjadi konsisten dengan berjalannya waktu. Sosiobudaya ini terdiri dari empat faktor utama, keanggotaan kita dalam kelompok menghubungi hubungan antarpribadi.

Dimensi psikobudaya mencangkup proses penataan pribadi (personal ordering process). Penataan pribadi ini adalah proses yang memberi stabilitas pada proses psikologis. Faktor faktor psikobudaya ini meliputi streotip dan sikap bangaimana orang lain akan berperilaku. Pengharapan kita itu pada giliranya mempengaruhi cara kita menafsirkan rangsangan yang datang dan prediksi yang kita buat mengenai perilaku orang lain. Menurut Mulyana (2014:171) etnosentrisme, misalnya mendorong kita menafsirkan perilaku orang lain berdasarkan kerangka rujukan kita sendiri dan mengharapkan orang lain berperilaku sama seperti kita. Hal ini akan membuat kita salah menafsirkan pesan orang lain dan meramalkan perilakunya yang akan datang secara salah pula.

Empat faktor yang dapat menghambat komunikasi antarbudaya sehingga orang menjadi tidak kompeten, yaitu stereotip, prasangka, etnosentrisme, dan diskriminasi. Keempatnya berpotensi menjadi titik tolak problem sosial. Eksistensi stereotip, prasangka, etnosentrisme, dan diskriminasi menjadi penentu atas penerimaan atau penolakan hubungan selanjutnya pada orang yang mempunyai latar belakang budaya berbeda.

Etnosentrisme menurut berasal dari bahasa Yunani ethnos (nation) atau bangsa dan kentron (center) atau pusat. Kita cenderung etnosentris tentang negara kita, daerah kita, atau kelompok etnik kita. Kita cenderung menganggap bahwa misalnya musik kita, makanan, seni, atau sistem politik kita terbaik dan terpenting.(Mulyana, 2014)

Nanda \& Warms dalam (Samovar, Porter, \& McDaniel, 2014) menyatakan bahwa etnosentrisme merupakan pandangan bahwa budaya seseorang lebih unggul dibandingkan dengan budaya yang lain. Pandangan bahwa budaya lain dinilai berdasarkan standar budaya kita. Kita menjadi etnosentris ketika kita melihat budaya lain melalui kacamata budaya kita atau posisi sosial kita.

Etnosentrime adalah "paham" dimana para penganut suatu kebudayaan atau suatu kelompok suku bangsa selalu merasa lebih superior daripada kelompok lain di luar mereka. Etnosentrisme dapat membangkitkan sikap "kami" dan "mereka", lebih khusus lagi dapat membentuk subkultursubkultur yang bersumber dari suatu kebudayaan yang besar. (Liliweri, 2013)

Konsep etnosentrisme itu tidak selalu negatif (Tubbs \& Moss, 2008). Sejalan dengan Tubbs \& Moss, (Liliweri, 2013) berpendapat bahwa sikap nasionalisme merupakan salah satu 
bentuk etnosentrisme, misalnya orang Amerika merasa lebih superior daripada orang Cina atau Indonesia. Sementara itu, Hybels berargumen bahwa patriotisme berbeda dengan etnosentrisme. Patriotisme itu merupakan kesetiaan seseorang pada negaranya sedangkan etnosentrisme lebih ekstrim dimana seseorang tidak percaya bahwa budaya, perilaku, norma, dan cara berpikir orang lain sebaik dan seberharga budayanya. Etnosentrime menjadi hambatan komunikasi antarbudaya ketika seseorang tidak pernah melihat sesuatu hal dari perspektif orang lain. (Hybels \& Weaver II, 2009)

Stereotip yakni menggeneralisasi orang-orang berdasarkan sedikit informasi dan membentuk asumsi mengenai mereka berdasarkan keanggotaan mereka dalam suatu kelompok. Dengan kata lain penstereotipan adalah proses menempatkan orang-orang dan objek-objek ke dalam kategori-kategori yang mapan, atau penilaian mengenai orang-orang atau objek-objek berdasarkan kategori-kategori yang dianggap sesuai, ketimbang berdasarkan karakteristik individual mereka.(Mulyana, 2014)

Orang melakukan stereotip pada umumnya karena orang tersebut merasa konsep dirinya terancam. Dengan kata lain, persepsi tentang diri memainkan suatu peran dalam seberapa besar kita strereotip terhadap orang lain. Banyak dari studi lintas budaya mengidentifikasi bahwa media massa terutama televisi merupakan sumber informasi mengenai budaya-budaya orang lain. Para peneliti menaruh perhatian pada tayangan-tayangan televisi atau film yang membuat suatu framing misalnya bangsa Arab dikesankan sebagai teroris. Kesan tersebut kemudian menjadi penyebab orang stereotip terhadap bangsa Arab yang dinilai sebagai bangsa teroris.(Tubbs \& Moss, 2008)

Stereotip tidak selalu negatif, misalnya stereotip terhadap bangsa atau suku tertentu yang dikesankan pelit, jorok, bodoh, malas, dan sebagainya. Stereotip bisa juga positif misalnya orang berfikir bahwa etnik atau bangsa tertentu itu sebagai bangsa yang rajin, pintar, pekerja keras, dan sebagainya (Devito, 2009). Terlepas dari stereotip itu negatif atau positif, sekali kita melakukan stereotip akan sulit menghilangkannya. Stereotip kadang-kadang hadir di alam bawah sadar sehingga orang tidak menyadarinya.(Hybels \& Weaver II, 2009)

Prasangka adalah suatu kekeliruan persepsi terhadap orang yang berbeda. Prasangka adalah sikap yang tidak adil terhadap seseorang atau suatu kelompok. Prasangka juga berarti penilaian berdasarkan keputusan dan pengalaman terdahulu. Richard W. Brislin mendefinisikan bahwa prasangka sebagai sikap tidak adil yang menyimpang atau tidak toleran terhadap sekelompok orang. Seperti juga stereotip, meskipun dapat positif atau negatif, prasangka umumnya bersifat negatif.(Mulyana, 2014)

Diskriminasi adalah tindakan terbuka yang diambil seseorang untuk mengecualikan, menghindarkan atau menjauhkan seseorang dari suatu kelompok. Diskriminasi ini mengandung sterotip dan prasangka dan satu langkah lebih jauh karena disertai tindakan baik tertutup maupun terang-terangan. Seseorang dapat dianggap melakukan tindakan diskriminasi jika dia memalingkan badan ketika berada dalam suatu percakan, melakukan kekerasan fisik untuk mengeluarkan orang dari suatu kelompok, atau mengecualikan orang dalam mendapatkan kesempatan kerja. Tindakan diskriminasi dapat terjadi secara antarpribadi, kelompok pada orang tertentu, atau institusi kepada seseorang atau sekelompok orang tertentu. (Hybels \& Weaver II, 2009)

Konsep-konsep dalam komunikasi antarbudaya di antaranya adalah proksemik, kronemik. Proksemik yang bisa dimaknai dengan penggunaan jarak atau space dalam berkomunikasi merupakan hal penting dalam komunikasi antarbudaya. Edward Hall, perintis awal konsep proxemics mengatakan bahwa ruang atau jarak berinteraksi, memberikan makna pesan yang sangat penting. Dalam budaya tertentu di Indonesia, bersalaman merupakan pertanda persahabatan. Namun ditempat lain, ternyata tidak hanya berjabat tangan, tapi juga berpelukan, dan membungkukkan badan menjadi indikasi suatu keakraban. Setiap budaya memaknai secara berbeda setiap bentuk kedekatan itu. Hall mencatat bahwa di dalam kebudayaan yang berbeda, maka jarak sosialnya akan berbeda. Pada kebudayaan negeri-negeri Latin, contohnya, jarak interaksi antarmanusia lebih dekat dan terasa akrab. Hal yang sebaliknya terjadi pada masyarakat di Eropa Utara. Menyadari dan menganggap bahwa perbedaan budaya ini meningkatkan pemahaman antar-budaya dan membantu menghilangkan ketidaknyamanan orang ketika merasa jarak mereka terlalu jauh atau 
terlalu dekat. Jarak sosial yang nyaman juga bergantung pada budaya, situasi sosial, gender dan kesukaan orang. (Hall, Edward T. (1966). The Hidden Dimension. Anchor Books at https://id.wikipedia.org/wiki/Proksemik, diakses tanggal 1 Juni 2019

Kronemik adalah bidang yang mempelajari penggunaan waktu dalam komunikasi nonverbal. Penggunaan waktu dalam komunikasi nonverbal meliputi durasi yang dianggap cocok bagi suatu aktivitas, banyaknya aktivitas yang dianggap patut dilakukan dalam jangka waktu tertentu, serta ketepatan waktu (punctuality).

Waktu sendiri terbagi menjadi dua: waktu monokronik (tepat dan serba diperhitungkan) dan polikronik (lebih santai). Kegagalan seorang penutur dalam memahami hal ini, bisa berakibat pada kesia-siaan pesan verbal yang mungkin telah disampaikannya. (Hidayatullah, 2017)

Hal selanjutnya membedakan budaya konteks tinggi (high context culture) dengan budaya konteks rendah (low context culture). Budaya konteks tinggi, ditandai dengan penyajian pesan komunikasi tidak secara eksplisit, tidak fokus ke persoalan, terlalu banyak basa-basi. Singkatnya, tidak mengungkapkan secara terbuka apa yang menjadi masalah. Sebaliknya, budaya konteks rendah, cenderung menyajikan pesan secara eksplisit, bicara langsung, lugas dan berterus terang. Berbagai penelitian seperti yang dilakukan oleh Turistiati menunjukkan bahwa etnik di Indonesia berdasarkan budaya komunikasinya melakukan komunikasi high context sering berbasa-basi, namun orang Jepang dibandingkan orang Indonesia lebih high context karena banyak makna pesan tersirat dalam komunikasi non-verbal.(Turistiati, 2019b)

Dalam penelitian ini penulis mengacu pada model komunikasi antarbudaya dari William B. Gudykunst dan Young Yun Kim, yakni komunikasi antara orang orang yang berasal dari budaya yang berlainan, atau komunikasi dengan orang-orang asing (stranger). Model komunikasi ini pada dasarnya sesuai dengan komunikasi tatap muka, khususnya antara dua orang. Meskipun disebut model komunikasi antarbudaya atau model komunikasi dengan orang asing, model komuniasi tersebut mempresentasikan komunikasi antara siapa saja, karena pada dasarnya tidak ada dua orang yang mempunyai budaya, sosiobudaya dan psikobudaya yang persis sama. (Mulyana, 2014). Selain itu penulis menggunakan konsep-konsep dalam komunikasi antarbudaya dari Edward T. Hall seperti proksemik (konsep jarak), kronemik (konsep waktu), high context and low context communication, individualisme dan kolektivisme, stereotip.

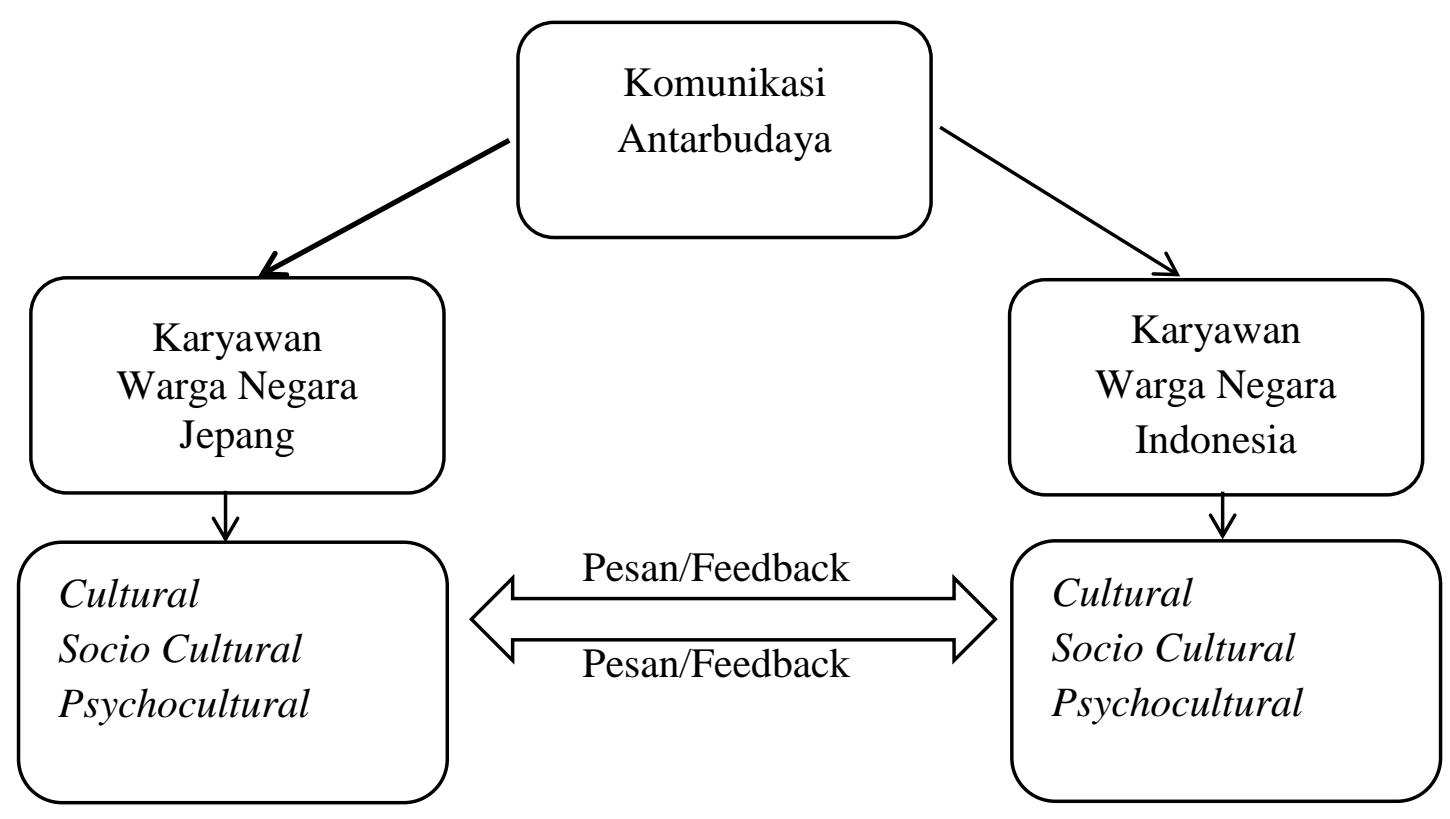

Gambar 2.2 Model Konseptual Komunikasi Antarbudaya Karyawan Warganegara Jepang dan Indonesia di PT. Tokyu Land Indonesia, diadaptasi dari Model Komunikasi Antarbudaya Gudykunst and Kim 


\section{METODE PENELITIAN}

Penelitian ini menggunakan pendekatan deskriptif kualitatif dengan jenis penelitian studi kasus. Pendekatan kualitatif menurut West \& Turner (2013: 77) dalam Turistiati (2019) berkaitan dengan realitas sosial yang bersifat subjektif. Selaras dengan pandangan tersebut, peneliti tidak melakukan analisis statistik. Namun, peneliti merangkum dan menganalisis kumpulan cerita dan pendapat dari informan, hasil observasi, dan kajian literatur, kemudian mengolahnya menjadi sebuah laporan.

Peneliti menggunakan jenis penelitian studi kasus dalam penelitian ini. Studi kasus diartikan sebagai metode atau strategi dalam penelitian untuk mengungkap kasus tertentu. Ada juga pengertian lain, yakni hasil dari suatu penelitian sebuah kasus tertentu. Dalam penelitian ini yang menjadi kasus adalah komunikasi antarbudaya antara karyawan warganegara Jepang dan Indonesia di PT. Tokyu Land Indonesia. Kasus yang terjadi di PT. Tokyu Land Indonesia bisa jadi sama atau berbeda dengan kasus yang terjadi di tempat lain.

Penelitian studi kasus memusatkan perhatian pada satu objek tertentu yang diangkat sebagai sebuah kasus untuk dikaji secara mendalam sehingga mampu membongkar realitas di balik fenomena. Sebab, yang kasat mata hakikatnya bukan sesuatu yang riel (realitas). Itu hanya pantulan dari yang ada di dalam.

Sebagaimana lazimnya perolehan data dalam penelitian kualitatif, data studi kasus dapat diperoleh dari semua pihak yang bersangkutan dalam hal ini masing-masing 3 orang karyawan warganegara Indonesia dan Jepang (total 6 orang). Teknik pengumpulan data melalui wawancara, observasi, partisipasi, dan dokumentasi. Data yang diperoleh dari berbagai cara itu hakikatnya untuk saling melengkapi.

\section{HASIL PENELITIAN DAN PEMBAHASAN}

PT.Tokyu Land Indonesia adalah anak perusahaan Tokyu Fudosan Holdings, perwakilan pengembang realestate yang komprehensif dari Jepang. Ikatan antara Indonesia dan Tokyu Land Corporation kembali tahun 1975 di Bandung. Pada tahun 1981, Tokyu Land Corporation memperluas bisnis ke Jakarta. Hingga saat ini, Tokyu Land Corporation telah menciptakan rekam jejak membuat 4.500 unit rumah hunian di Jakarta.

PT. Tokyu Land Indonesia didirikan pada tahun 2012 dengan tujuan memanfaatkan keterampilan dan kepercayaan yang telah dibangun lebih dari 40 tahun. Selain itu, kekayaan pengalaman sebagai perusahaan pengembang yang komprehensif di Jepang dan kekuatan kolektif yang dimiliki oleh Tokyu Group untuk merintis \& mengembangkan bisnis baru di Indonesia. Setelah berdiri dengan baik, pada tahun 2015 PT. Tokyu Land Indonesia meluncurkan merek kondominium yang telah dikembangkan di Jepang "BRANZ" di Indonesia. Ini adalah pertama kalinya sebuah perusahaan Jepang mengembangkan merek kondominium Jepang di luar negeri, dan mewakili keinginan kuat untuk menciptakan akar di Indonesia serta untuk tumbuh dan berkembang bersama di negeri ini. Selain bisnis penjualan kondominium, PT.Tokyu Land Indonesia juga bertujuan untuk mengatasi tantangan leasing dan manajemen bisnis ke depan.Ini adalah keinginan PT.Tokyu Land Indonesia untuk memberikan sesuatu yang lebih untuk Indonesia dengan menciptakan nilai baru melalui penggabungan kebutuhan pelanggan Indonesia dengan kualitas tinggi yang ditawarkan oleh Jepang.

\section{Komunikasi Antarbudaya antara Karyawan Warganegara Jepang dan Indonesia di PT.Tokyu Land Indonesia}

Para informan penelitian memiliki latar belakang budaya yang berbeda. Karyawan Indonesia ada yang bersuku Batak, Jawa dan Sunda. Karyawan Jepang berasal dari Tokyo, Osaka, dan Fukuoka yang memiliki budaya yang berbeda pula dalam konteks aksen dan gaya berbicara.

Komunikasi antarbudaya antara karyawan warganegara Jepang dengan Indonesia di PT. Tokyu Land Indonesia berupa pertukaran informasi, saling menyampaikan pesan, pendapat, usulan dalam pertemuan/rapat, berdiskusi untuk menyelesaikan suatu masalah atau konflik, melakukan 
negosiasi bisnis, dan lain-lain. Aktivitas komunikasi tersebut dilakukan baik secara verbal maupun non-verbal.

Berdasarkan pengamatan peneliti, karyawan Jepang dan Indonesia pada umumnya relatif dapat berkomunikasi antarbudaya dengan baik. Karyawan Indonesia lebih memilih "aman". Jika karyawan Indonesia diminta untuk mengerjakan suatu tugas oleh orang Jepang, karyawan Indonesia selalu berusaha siap melakukannya. Jika karyawan Indonesia kurang atau bahkan tidak paham permintaan atau perintah orang Jepang, karyawan Indonesia kadang-kadang memilih bertanya pada sesama karyawan Indonesia.

Karyawan Jepang dalam banyak kesempatan pada umumnya akan bertanya terlebih dahulu kepada karyawan Indonesia apakah karyawan Indonesia sibuk untuk melakukan perintahnya. Hal ini dilakukan orang Jepang seperti "basa-basi" karena walaupun karyawan Indonesia sibuk, orang Jepang tersebut berharap karyawan Indonesia dapat melakukan perintah/pekerjaannya.

Orang Jepang seperti apa yang dikatakan Hall merupakan masyarakat dengan high context cultural/communication. Mereka melakukan basa-basi dan jika menyampaikan pesan secara tidak langsung atau tidak to the point.

Dalam konteks aktivitas komunikasi antarbudaya di lingkungan kerja, karyawan Jepang secara cultural dan socio cultural dikenal sebagai orang yang memelihara kolektivisme. Berdasarkan pengamatan peneliti, karyawan Jepang memerlukan waktu yang cukup lama untuk membuat keputusan akan suatu penyelesaian masalah. Orang Jepang sangat menjunjung tinggi terciptanya keharmonisan dalam hubungan kerja. Agar keputusan dapat diambil dengan meminimalisir konsekuensi yang kurang baik pada anggota kelompok, orang Jepang tersebut mendiskusikannya dengan atasannya. Keputusan yang dibuat karyawan Jepang seringkali dinilai oleh karyawan Indonesia terlalu lama.

Karyawan Jepang disiplin dan menghormati waktu. Orang Jepang jika berjanji akan bertemu, misalnya bertemu untuk melakukan rapat jam 08:00 maka dia akan datang sebelum jam 08:00 atau paling lambat jam 08:00. Karyawan Indonesia kadang-kadang datang lebih dari jam 08:00. Orang Jepang tidak menegur secara langsung atas keterlambatan tersebut tetapi non-verbal mereka melalui bahasa tubuh atau pandangan matanya menunjukkan kesan kurang suka. Hal tersebut peneliti amati secara langsung dalam observasi sehari-hari ketika melakukan penelitian.

Disiplin merupakan salah satu faktor penting dalam keberhasilan mencapai target-target perusahaan. Karyawan Indonesia belajar dari disiplin orang Jepang masalah mengelola waktu. Orang Jepang dikenal sangat disiplin dalam mengalokasikan dan mengelola waktu. Budaya tepat waktu dalam memenuhi janji, melaksanakan dan menyelesaikan tugas serta kewajiban menjadi rujukan bagi karyawan Indonesia.

Disiplin dapat diartikan sebagai sikap seseorang atau kelompok yang berniat untuk mengikuti aturan-aturan yang telah ditetapkan. Dalam kaitannya dengan pekerjaan, disiplin kerja adalah suatu sikap dan tingkah laku pegawai/karyawan terhadap peraturan organisasi.

Karyawan Jepang di PT. Tokyu Land Indonesia cukup toleran terhadap karyawan Indonesia yang beragama Islam. Sikap toleran karyawan Jepang ditunjukkan dengan membiarkan atau memberi izin pada kayawan muslim menjalankan ibadahnya di kantor. Misalnya, pada saat karyawan muslim melakukan shalat dan puasa, menyediakan tempat bagi karyawan muslim untuk melaksanakan shalat. Demikian pula karyawan Indonesia yang beragama Islam bertenggang rasa ketika orang Jepang misalnya mengkonsumsi makanan yang mengandung daging babi atau minum minuman yang mengandung alkohol. Sebaliknya, orang Jepang memberi tahu apabila ada makanan yang mengandung bahan-bahan yang tidak boleh (haram) dikonsumsi oleh orang Islam, seperti daging babi, alkohol, dan sebagainya.

Toleransi beragama pada prinsipnya merupakan sikap saling menghormati dan menghargai penganut agama lain. Tumbuhnya sikap toleransi membuat hidup damai saling berdampingan dan menghindarkan kebencian serta permusuhan. 
Hambatan yang Terjadi di dalam Komunikasi Antarbudaya antara Karyawan Warganegara Jepang dengan Indonesia di PT.Tokyu Land Indonesia dan cara Mengatasi Hambatan Tersebut

\section{a. Pemahaman dan Penguasaan Bahasa oleh Informan}

Hambatan komunikasi antarbudaya dapat terjadi karena beberapa hal dan akibatnya komunikasi berjalan tidak efektif. Hambatan komunikasi atau yang juga dikenal sebagai communication barrier adalah segala sesuatu yang menjadi penghalang untuk terjadinya komunikasi yang efektif.

Masing masing informan memiliki tingkat penguasaan bahasa Inggris yang berbeda beda. Misalnya Informan KB dan KT memiliki penguasaan bahasa Inggris yang baik, sementara penguasaan bahasa Indonesia-nya kurang.

Kesalahpahaman dalam berkomunikasi kadang-kadang terjadi antara karyawan Jepang dan Indonesia di PT. Tokyu Land Indonesia. Misalnya, informan SZ warganegara Jepang. yang telah tinggal selama 21 tahun di Indonesia pun masih mengalaminya. SZ mengatakan:

"Contohnya si A menjelaskan sesuatu dengan tidak jelas, kurang lengkap permasalahanya.

Karena setiap orang mempunyai daya tangkap yang berbeda-beda. Contohnya bila berbicara dengan si A cukup 1 kali saja, tapi dengan si B harus berulang ulang"

SZ mengatasi kesalapahaman tersebut dengan menjelaskan kembali secara terperinci. Pada kesempatan lain SZ akan lebih berhati-hati berbicara dengan orang tersebut. Seperti yang dijelaskan sebelumnya karyawan Indonesia kadang-kadang mengatakan paham jika dijelaskan sesuatu namun sebenarnya belum paham. Karyawan Indonesia berdasarkan pengamatan peneliti nampak seperti malu atau takut jika terlalu banyak bertanya.

Karyawan orang Indonesia menurut SZ sangat ramah terhadapa orang lain, apalagi terhadap orang Jepang. Namun, beberapa karyawan Indonesia kadang-kadang kurang menghargai waktu. Misalnya, datang terlambat ke kantor dengan alasan macet dan susan mencari atau lama menunggu transportasi.

Informan KB warganegara Jepang lainnya mengalami kesalahpahaman pada saat membuat surat perjanjian atau penawaran yang didapat dari vendor sering terjadi kesalahan. Apa yang dikerjakan karyawan Indonesia sering tidak sama sama dengan apa yang diinginkanya dengan kenyataanya. Contoh lain dalam pembelian barang barang untuk kebutuhan pekerjaan kadangkadang terjadi kesalahan. Hal tersebut lebih banyak karena kendala bahasa dari kedua belah pihak. KB merasa bahasa Indonesia-nya belum begitu pasih dan pengucapannya yang kurang pas atau pemilihan katanya yang kurang tepat. Karyawan Indonesia pun ada kemungkinan salah tafsir dan tidak melakukan konfirmasi. Sehingga antara KB dan staff nya sering timbul miss communication atau kesalapahaman

KB menanggulangi masalah kendala bahasa dengan cara menjelaskan berulang dan meminta konfirmasi apakah karyawan Indonesia tersebut sudah paham atau belum. Orang Indonesia menurut KB memiliki sikap yang kadang-kadang tidak peduli dengan kesalahan yang dibuat, sedangkan orang Jepang sekecil apapun kesalahan bagi mereka adalah fatal. Informan KT, warga negara Jepang mengalami hambatan dengan karyawan Indonesia jika harus melakukan penjelasan yang panjang dan rumit dengan bahasa Indonesia. Selain karena faktor bahasa Indonesia yang kurang dikuasi, orang Indonesia pun kurang menguasai bahasa Jepang terutama istilah teknisnya. Orang Indonesia kadang-kadang tidak menyadari kesalahan yang dilakukan, takut mengakui kesalahan alasanya karena takut atau ada alasan yang lain. Jika terjadi kesalahpahaman karyawan Jepang dan Indonesia mendiskusikannya lagi sampai akhirnya mereka saling memahami maksud yang sebelumnya dikomunikasikan. Menurut KT, orang Indonesia memiliki sifat periang dan bersahabat. Sejalan dengan pendapat SZ dan KB, KT menyatakan bahwa karyawan Indonesia kadang-kadang kurang menghargai waktu, sehingga misalnya datang terlambat ke kantor atau pada acara rapat. Alasan yang dibuat karena macet atau masalah transportasi.

MW karyawan Indonesia menyatakan bahwa kesalahpahaman yang terjadi antara dirinya atau karyawan Indonesia terhadap karyawan Jepang dikarenakan orang jepang memiliki 
pengucapan yang kurang jelas dan terdengar aneh, terutama jika orang Jepang menggunakan bahasa Inggris.

\section{b. Stereotip}

Stereorip terjadi dari orang Jepang ke orang Indonesia dan sebaliknya. Stereotip orang Jepang misalnya, orang Jepang itu pelit, kaku, disiplin, menghargai kebersihan, hard worker atau pekerja keras. Orang Indonesia sering distereotipkan sebagai orang yang tidak disiplin terhadap janji atau waktu dan menganut 'jam karet', ramah, jorok, mudah diajak kompromi. Perbedaan penghargaan terhadap waktu (kronemik) kadang-kadang menimbulkan masalah dan komunikasi tidak berlangsung efektif.

Dari hasil penelitian ini, penulis menemukan bahwa antara karyawan PT. Tokyu Land Indonesia warga negara Jepang dan Indonesia saling menghormati. Walaupun sering terjadi kesalapahaman dalam bekerja akan tetapi untuk komunikasi pribadi berjalan dengan baik. Karyawan Indonesia memahami kendala yang dialami oleh karyawan Jepang dalam segi berbahasa. Karyawan Jepang juga memahami budaya orang Indonesia yang kurang bisa untuk menepati dan menghargai waktu. Untuk karyawan Jepang ditemukan kurangnya bersosialisasi kepada karyawan Indonesia sehingga terlihat sombong atau angkuh dimata karyawan Indonesia.

\section{SIMPULAN DAN SARAN}

\section{Simpulan} bahwa:

Berdasarkan uraian dan analisis yang telah dipaparkan di atas, dapat ditarik simpulan

1. Komunikasi antarbudaya antara karyawan Jepang dan Indonesia di PT. Tokyu Land Indonesia relatif berjalan baik.

2. Hambatan yang terjadi dalam komunikasi antarbudaya karena masalah perbedaan dan pemahaman bahasa, kebiasaan, penghargaan terhadap waktu (Jepang monokronik sementara Indonesia polikronik), dan adanya stereotype dari masing-masing bangsa. Bahasa merupakan faktor utama yang sering menyebabkan hambatan komunikasi antarbudaya. PT. Tokyu Land Indonesia mengunakan bahasa ke-tiga yaitu bahasa Inggris sebagai bahasa komunikasi sehari hari. Karyawan Jepang yang menggunakan aksen atau logat bahasa ibu yang dibawa ke dalam bahasa Inggris mengakibatkan karyawan Indonesia terkadang sulit untuk memahami apa yang diucapkan atau diutarakan oleh karyawan Jepang. Penjelasan yang kurang jelas menjadi faktor terjadinya kesalapahaman. Karyawan Indonesia juga bila mendapat penjelasan yang kurang jelas tidak menayakan kembali untuk memastikan agar tidak terjadi kesalapahaman.

3. Cara mengatasi hambatan tersebut dengan lebih mempelajari budaya Jepang bagi karyawan Indonesia, dan budaya Indonesia bagi karyawan Jepang, keterbukaan untuk mengkonfirmasi pemahaman terhadap pesan yang disampaikan, saling menghormati, dan saling memaafkan jika terjadi kesalahpahaman.

\section{Saran}

Untuk melengkapi hasil penelitian ini, peneliti mengajukan beberapa saran atau rekomendasi sebagai berikut:

1. Saran Akademik

Penelitian ini masih dapat dikembangkan atau dieksplorasi lebih luas dengan metode penelitian yang berbeda misalnya, metode penelitian kuantitatif di mana peneliti dapat menguji seberapa besar pengaruh budaya pada huungan interpersonal (antar peribadi)

2. Saran praktis

Sebagai masukan ke depannya, baik karyawan warga negara Jepang maupun Indonesia dapat lebih banyak belajar mengenai budaya orang lain, saling bertoleransi, dan terbuka untuk saling mengingatkan untuk perbaikan hubungan. 


\section{DAFTAR PUSTAKA}

Arifin, C. (2019). Sepanjang 2018, Jumlah Pekerja Asing di Indonesia Naik 10,88. Retrieved from https://www.tribunnews.com/bisnis/2019/01/13/sepanjang-2018-jumlah-pekerja-asing-diindonesia-naik-1088-persen-jadi-95335-orang

Aryandani, J. (2016). Pola Komunikasi Antarbudaya pada Komunitas Korea Hansamo di Bandung,. Retrieved from http://repository.unpas.ac.id/view/year/2016.type.html)

Devito, J. A. (2009). The Personal Communication Book (12th Editi). New York: Pearson Education.

Griffin, E. (2006). A First Look atof Communication Theory. USA: Mc.Grawhill.

Hidayatullah, S. (2017). BAHASA KOMUNIKASI NONVERBAL Pengirim Pesan tanpa Kata. Jakarta. Retrieved from http://repository.uinjkt.ac.id/dspace/bitstream/123456789/32442/3/Bahasa Komunikasi Nonverbal Moch. Syarif.pdf

Hybels, S., \& Weaver II, R. (2009). Communicating Effectively. New York: McGraw-Hill Companies.

Liliweri, A. (2013). Dasar-Dasar Komunikasi Antarbudaya. Yogyakarta: Pustaka Pelajar.

Mulyana, D. (2014). Pengantar Ilmu Komunikasi. Bandung: Rosda Karya.

Rahayuningsih, I. (2014). Komunikasi Lintas Budaya dalam Organisasi (Studi Kualitatif) melalui Masyarakat Ekonomi Asean (MEA”. Retrieved from http://journal.umg.ac.id/index.php/psikosains/article/view/241

Samovar, L. A., Porter, R. E., \& McDaniel, E. R. (2014). Komunikasi Lintas Budaya (Terjemahan Communication Between Cultures) (Edisi 7). Jakarta: Salemba Humanika.

Siregar, I. (2017). Komunikasi Antarbudaya Mahasiswa Malaysia dan Indonesia Fakultas Dakwah dan Komunikasi di UIN Sumatera Utara. Retrieved from \%0Ajurnal.uinsu.ac.id/index.php/balagh/article/view/1234\%0A\%0A

Tubbs, S., \& Moss, S. (2008). Human Communication, (11th Editi). New York: McGraw-Hill Companies.

Turistiati, A. T. (2019a). Kompetensi Komunikasi Antarbudaya (1st ed.). Jakarta: Mitra Wacana.

Turistiati, A. T. (2019b). Strategi Adaptasi Mahasiswa Indonesia di Nara Jepang, Tinjauan Komunikasi Antarbudaya. Jurnal IDIK, Vol.1(No.1). Retrieved from http://jurnal.idikunpad.com/index.php/jik/article/view/4/6

Blog \& Wikipedia:

Anchor Books at https://id.wikipedia.org/wiki/Proksemik, diakses tanggal 1 Mei 2019

http://commscience166a.blogspot.com/2012/10/model-komunikasi-gudykunst-dan-young.html, diakses tanggal 1 Mei 2019 